\title{
職域集団における精液指標調査研究の実際と課題
}

\author{
上島 通 浩
}

名古屋大学大学院医学系研究科社会生命科学講座環境労衝衛生学

\section{Considerations When Conducting Study of Semen Indices in Workplaces}

\author{
Michihiro KAMIJIMA \\ Department of Occupational and Environmental Health, Nagoya University Graduate School of Medicine
}

\begin{abstract}
The possible adverse impact of environmental chemical exposure on semen quality is a public health concern. However, an epidemiological study targeting the general population is not easy. An alternative approach is to study workers exposed to higher doses of the concerned chemicals, whereas there have been only a very limited number of such studies conducted in Japan to date. This review, on the basis of the author's experience thus far, attempts to shed light on considerations when planning possible semen studies in workplaces in Japan. They include study design, informed consent of both the employer and participating employees, means of increasing participation ratio, control of nonexposure factors such as abstinence period and medical history, standardization in measuring semen indices, interpretation of study results, and necessary precautions when reporting a low semen quality in the exposed population.
\end{abstract}

Key words: workplace (職域), occupational exposure (職業性曝露), semen indices (精液指標), informed consent (説明と同意), epidemiological study（疫学研究）

\section{1.はじめに}

1992 年, Carlsen らが過去 50 年間でヒト精子数が半減 した可能性について報告（1）して以来，環境化学物質が 生殖機能に与える影響について関心が高まっている。し かし，一般生活環境中の微量な化学物質の同定・定量が 測定機器・技術の進歩により可能になった一方で，これ ら化学物質への曝露を原因として精子数の減少, 精子運 動性の低下, 形態異常精子の増加などの精液指標の变化 がヒトで生じているかについては，いまだ結論が得られ ていない。これは, 曝露が微量な一般環境で疫学研究を 実施し, 曝露と精液指標との関連を検討することが困難 であることを示している。一般生活者集団を対象とした 疫学調査が容易でないとすると，これに代わる手段とし ては，曝露による影響がある場合にそれを観察しやすい 集団，すなわち曝露量が多い集団でリスク評価を行い，

受付 2005 年 3 月 25 日, 受理 2005 年 7 月 12 日

Reprint requests to : Michihiro KAMIJIMA

Department of Occupational and Environmental Health, Nagoya University Graduate School of Medicine, 65 Tsurumai-cho, Showa-ku, Nagoya 466-8550, Japan

FAX: +81(52)744-2126

E-mail: kamijima@med.nagoya-u.ac.jp
その結果を用いて曝露量の少ない一般生活者集団のリス ク評価を行らことが考えられる。曝露量が多い集団の典 型としては, 影響の有無を検討すべき化学物質を製造し, または仕事で使用する職域作業者があげられる。このよ らな職域で実施する調査研究は, 法定の職域健康管理の 枠組みを利用できれば効率よく推進できるはずである が，残念ながら現状では日本の職域で実施された精液指 標に関する研究蓄積はきわめて少ない。その理由は, 職 域での疫学研究実施に必要な留意事項, 精液といら一般 的でない検体を扱ら技術的特殊性に加え，生殖機能とい ら個人のプライバシーに深く踏み込むと多くの人が感じ る内容を扱らことのむずかしさにある。フィールド研究 として精液指標調査を行う上での留意点に関しては Schraderによる総説 (2) がほほ網羅しているが, 本稿では 筆者のグループが試行錯誤を重ねた経験をふまえ, 職域 で毒性学的な視点での調査研究を行ら場合に最も問題と なる, 事業所や研究参加者とのコミュニケーションの内 容を含め, 日本国内の職域で実施する精液指標調査のあ り方について明らかにしたい。

\section{2. 職域における精液指標調查研究の疫学}

生体試料としての精液の入手は尿や血液等に比べ困難 
であることから, 精液採取を伴う研究の多くは検体入手 の比較的容易な不妊医療あるいは産婦人科医療の現場と 結びついて実施されている。環境毒性学分野の研究の対 象集団としては, 不妊外来受診者は曝露と無関係に妊孕 性の低下した人が最初から多く含まれるという点で一般 人口とは異なり, また, 産婦人科外来を受診した妊婦の 配偶者を対象にボランティアを募る方法は, 今度は子供 をもつ年齢層の妊孕力のある人のみが選択されるため, 独身者, 子供のいない人，子供をつくる時期を過ぎた人 もいる一般人口とは異なった集団とみなされる。これに 対し, 職域集団を対象に行ら研究は, 精液採取の問題に よる参加率の低ささ光解決すれば上記の欠点を回避で き，検討対象となる化学物質への曝露量も高いという， 医療機関ベースの研究にはない長所がある。

これまでに発表された職域での精液指標の調査研究 は, 症例群に関する記述研究によるハザード事例の報告 $(3,4)$ あるいは横断研究 (5-26) の手法によるものに大別 される(表 1)。ごく一部はパネル研究として時間軸を含 み, その場合は同一標本の曝露前後における, あるいは 曝露頻度の変化にともなら精液指標の変化の有無を検討 可能である $(7,18,19)$ 。曝露が指標悪化のリスクを増強 しているかどらかより直接的に明らかにするためには， $1 つ の$ 職域に颃いて前向きコホートを設定することが望 ましいが, 精液指標測定については 1 回限りの横断研究 実施すら容易でなく，今日までに発表されたコホート研 究は, 曝露作業者が不妊問題を抱えたことで知られる 1,2-ジブロモ-3-クロロプロパン（DBCP）（27）について の発表を除きほとんど存在しない。

職域に怙ける研究では, 精液指標変化の検出に必要な 標本の大きさの確保が最大の難所である。日本国内の職 域では近年省力化が著しく進み一事業所あたりの曝露者 が減っていて, 調査対象人数の限られる場合が少なくな い。これは, 精液指標に関する調査研究に特有の問題で はないが, 曝露者が少ない上に参加率が低い場合は, 適 切な対照群の設定に難橴し量反応関係の検討が困難とな る。曝露量が少なく大きな影響がみこまれない場合は， 調査前に参加者数が確定した時点で曝露群と非曝露群の 間で有意差の出ないことが予想されることになり，この ような場合は調査研究を実施すべきでないという考え方 もありらる。しかし, 参加者を募る手続きは事業所側の 了解を取り付けた後でなければ行えず,「参加率が低い場 合には調査は実施しません」といら姿勢では, 調査への 協力の可否を事業所の安全衛生委員会をはじめとする意 思決定プロセスにのせて検討してもららことはむずかし い。また, 対象者には参加者個々の健康管理より研究上 の関心が優先しているように受け取られる可能性があ り, その場合研究参加呼びかけの説得力に欠けるであろ ら。しかし困ったことに, 参加希望者が少ないことが明 らかになった段階で申込期間の延長とともに説明をさら に繰り返しても, 筆者の経験では精液調査への参加希望 者が新たに現れたことは汪とんどなく，参加率が上昇す
ることはまず望めない。

したがって, 職域で精液指標調查を行おらとする場合 は, 分析研究として成り立たなないことが判明しても調 査を実施する覚悟が必要である。表 1 に示すように, 調 查研究への参加率は最大でも 3 割と見積もるのが現実的 であり, 対象職域の人数とこの 3 割といら数字が, 分析 的横断研究として成立するか, また調査全体にどの程度 の時間と器材などの資源が必要か検討する上で出発点と なる。研究実施にあたっては $\mathrm{p}$ 值や信頼区間の記載を行 い, 結果の判断を読者に委ねるとともに将来のメタアナ リシスに使用できる情報を残すよう努力すべきである が, 不幸にも参加者数がきわめて少ない場合は, 各被験 者の曝露の状況と精液指標所見の記述研究として調査を 行ら。その場合も, 研究参加者や協力した事業所に対す る産業保健サービスとしての側面には変化がないことを 忘れるわけにはいかない。

\section{3. 事業所の理解と協力}

精液採取は結果の研究への利用を前提とする健康診断 として実施するが, 職域集団を対象とする以上, 被験者 のインフォームドコンセント取得手続き以前に事業所の 理解と協力を得ることが不可欠である。これは精液指標 調查研究に特異的な問題ではないが, 毒性学的な視点で の研究実施に必要な留意点がいくつか存在する。

職域集団に打ける生殖機能の保護は, 法的には労働基 準法, 労働安全衛生法に基づいて行われる。女性につい ては労働基準法第 6 章の 2 で, 妊産婦等の危険有害業務 への就業制限や生理休层等について定めているが, 男性 生殖機能保護の視点は法の中にない。一方, 労働安全衛 生法第 66 条 2 項による特殊健康診断では, 現状ではグリ コールェーテル類 $(28)$ や鉛 $(13,29)$ のように使用頻度 が高く, ヒトで精液質への毒性影響が起こりらることが 知られる化学物質についても, 健康診断項目に生殖機能 に関する検査や自覚症状の問猃は規定されていない。し たがって，精液質の健康管理，すなわち精巣毒性の予防 といら概念は事業所側にとってなじみがない。調査研究 の実施が従業員の健康管理に役立つと考光協力が得られ る状況なら理想的であるが, 生殖機能はプライバシ一性 が高く羞恥心も無視できない領域であるために, 私生活 への介入と考光実施に二の足を踏むのが通常の反応であ る。

また, 事業所側としては, 従業員の意思やプライバシー の尊重といら側面の他に, 潜在している生殖機能への影 響が検出された場合にどのように対処すべきかを考慮す る必要がある。その結果, 健康障害の発生を疑わせる結 果が得られた場合に従業員に対し責任を負えないとの理 由で協力を断られたり, 事業主が調査研究の意義を正し く認識しても, 社内の意思決定過程で産業保健スタッフ, 労働組合, 法務担当者を含むすべての関係者の合意を最 終的に得られなかったりしたことがあった。一方で成功 


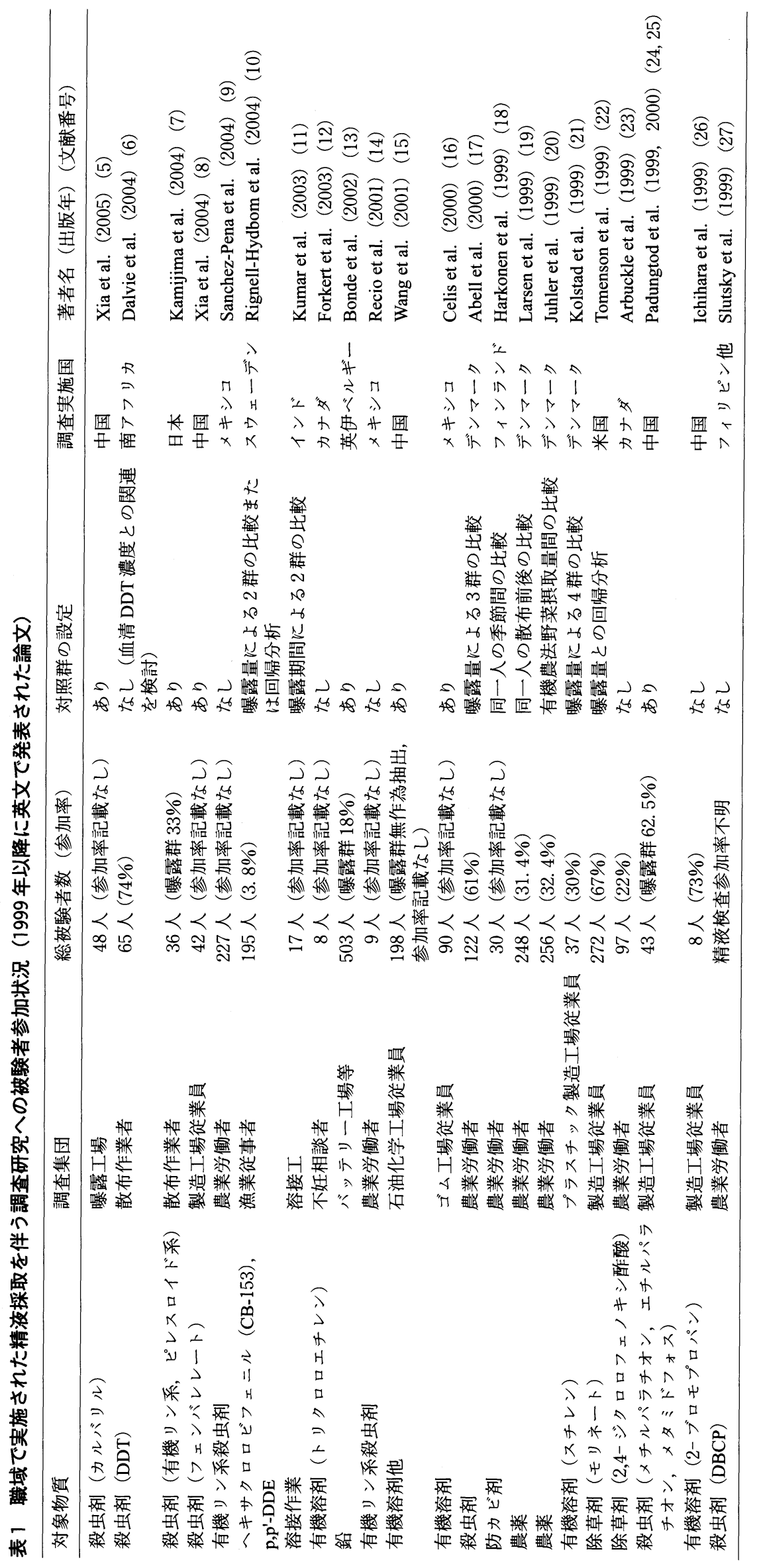


例としては，事業所の了承を得た上で安全衛生委員会に 出席する嘱託産業医を訪問し, 調査研究内容について説 明し理解を得たことにより，当初躊躇していた事業所の 姿勢が協力に転じた事例を経験している。

調査の実施方法としては，事業所が主宰する定期健康 診断の任意の付加項目として精液検查を含む研究的な健 康診断を行ら方法に加兄, 事業所が行う健康診断とは無 関係に事業所外飞会場を設定し, 事業所には個々の従業 員への参加協力依頼の橋渡しのみ拃願いする方法があ る。前者は事業所として従業員の参加状況を把握できる が, 健康診断結果が悪ければ何らかの対応を迫られる可 能性がある。一方, 後者の場合は調査研究としての健康 猃断への参加とその結果の利用は, 基本的に参加者が私 的に行うものと理解される。ぞちらの方法を受け入れや すいかは事業所により異なるが, 後者を望む場合が多い 印象を筆者は受けている。

いずれの実施方法にせよ, 毒性学的な視点での調査結 果は精液指標に限らず社会の関心事であり, 事業所は研 究結果への不安を常に持っている。対象化学物質によっ ては該当企業が限られるため, そのよらな場合は企業名 を匿名にして研究発表を行っても職域が特定される可能 性がある。労働安全衛生法に定めのない自主的な健康調 査を実施している姿勢が従業員はもとよりその企業に対 する地域社会や国民の信頼をより高める方向に働くか, あるいは研究として公表された調査結果がマスコミによ りセンセーショナルにとりあげられ, 企業や事業内容に ダメージを与える方向にむからかは, 研究者の結果発表 のしかた，マスコミの報道のしかた，市民運動家の行動， 情報を受け取る国民の側の態度によるところが大きいと 思われる。職域で毒性学的な研究を行う研究者なら誰で も理解していることであるが，未知の問題点を明らかに する視点だけで調査を行った場合, たと六健康管理の向 上や知見の収集に貢献できても, 協力した事業所が途方 に暮れる事態が生じうる。主治医が患者に対して責任を 負うのと同様に, 研究者側の道義的責任として, 事業所 及び研究参加者の双方に生じる問題の解決に協力するこ とが求められる。

\section{4. 被験者の理解と協力}

事業所の了承が得られたとして, 対象者の理解と協力 を得て精液採取を伴う調查研究への参加率をいかに上げ るかが課題である。子供を望むカップルの約 10-15\%は 不妊の問題を抱える (30) が, 生殖機能の健康管理という 概念は一般的とはいえず，精液を健康診断で提出するこ とには心理的抵抗がきわめて強い。電話での問い合わせ, アンケート, あるいは事業所の安全衛生担当者などを通 じてこれまでによせられた疑問や不参加者の声として は, エイズや梅毒その他の性病検査との誤解, 検診に参 加するのはその上うな病気が心配だからではないかと他 人に勘ぐられることの心配, 精液採取には侵襲的な苦痛
を伴らのではという心配，精液検査またはマスターベー ションへの抵抗, 子供がいるので検査の必要を感じない などの内容があった。プライバシーの保持に関しては, 調査研究への参加の有無を同僚に知られない上う, 参加 者同士が採精の前後出会わないなどの配慮は常に行って いるが，採精室を事業所内に設定した時は職場内で受診 の秘密を保つのは事実上不可能であった。ちなみに, 参 加者の受診時刻の設定においては，採精に要する時間の ばらつき (平均 15 分程度であるが 30 分以上かかる場合 もある）や液化待機時間 30 分, 1 検体の測定に要する時 間（15～30 分）, 被験者の動線上で他人と会わないため の予備時間を考慮し, 最低 $45 \sim 60$ 分は被験者間の間隔 をあけるようにしている。

精子数の計測が主要な目的であれば精液採取は自宅で 行い持参してもらら方法もありらるが，次章で述べるよ らに分析前の検体取り扱いに留意する必要が生じ煩雑で ある伍かに, 頻度が高くかつ精液所見を悪くすることが 知られている精索静脈瘤 (31) の診察や精巣容積の測定 を，健康診断の一体の流れの中で実施することがむずか しくなる。ちなみに, この生殖器系の診察も参加者の心 理的抵抗感を高める要因の 1 つであり, 同じ内容の説明 と同じ泌尿器科専門医による診察を実施しても, 診察を 病院の外来で行った時には比較的問題にならず, 事業所 内の一室で行った時に説明が足りないとの指摘を受けた 経験がある。同じ手続きを踏んで健康診断を行っても, 実施場所が事業所内か医療機関内であるかによって参加 する側の意識が微妙に変わる可能性は, 生殖器を扱う調 査研究以外では通常問題にならないだろらと考えられ る。

調査研究の目的と意義，参加するメリット，デメリッ 卜について対象者に十分説明し，正しい理解を得て心理 的な抵抗感を弱くするために，ぞらいら場で誰がどのよ らに説明するとより効果的であるかについては，今後明 らかにされるべきであるら。事業所を通じて案内を出し， 関心を示した人に再度詳しい内容を送付する方法, 事業 所の安全衛生委員会での承認を経て従業員への説明会を 開く方法をこれまでに経験しているが, 説明会当日に参 加者側から質問が寄せられた経験は少ない。後日，匿名 の電話で「精液採取には痛い器具を使いますか?」と尋 ねられたことが複数回あり，なじみのない健康診断につ いての説明は，文章や話の中で言葉を尽くしたつもりで も内容が伝わりにくいこと，集団での説明会では質問が あっても尋祖にくいことを実感した。この点で参考にな りらる例として, 保健師を含む研究チームが研究参加者 の自宅を訪問し夫婦両方に対して説明を行った上で採 精, 採血を行った，スウェーデンの漁業従事者集団を対 象とした研究 (10) がある。しかし, 自宅を訪問する場合 は前述した生殖器の診察評価は事実上不可能で, また, 自宅には来てもらいたくない人るいることを考虑する必 要があろう。

上記の他に心理的抵抗感を弱め参加率を高めるための 
方法としては, 調查研究への参加が個人の健康管理に還 元されることを基本にしつつも，参加者の受診の手間や 休業による減収分を補償する日当相当額の研究協力謝金 を支払う場合があり $(2,23,32)$ ，これは国を問わずこの 領域の研究者の共通の認識になっている。しかし，法定 健康診断にあわせて事業所内で実施する場合は，謝金を 支払らことは行いにくい。

また，調査を事業所の健康診断とは別個に事業所外で 実施する場合は，会場や時間の設定において受診しやす さを考慮することも重要である。前述の不参加者へのア ンケートでは，受診場所が不便である，忙しくて時間が とれないという回答があった。表面上は調査研究実施の 了解が得られても, 従業員が実際に参加するかしないか は調査実施期間内の仕事や勤務時間割の組まれ方に大き く左右され，特定の企業の参加希望者から「仕事の都合 がつかず参加できない」と連絡が入り，結果的にその企 業からの参加者がゼロだった経験がある。すなわち，こ の場合の事業主としての態度は, 会社と無関係に実施さ れる調査研究への従業員の参加は仕事に差し支えない限 り自由であるが, 参加しやすいような配慮は特にしない, といらことであり，事業所に協力していただいた内容が 個々の従業員への参加依頼の橋渡しのみである以上，そ れももっともなものとして理解できる。ちなみに，企業 の研究者が著者に名を連ねている職域精液指標調査研究 の参加率は高く，その企業や業界が危機感や問題解決の 必要性を感じていることが論文かららかがわれる(22)。 そのような状況はまれであり, 通常は研究者側が対象者 の都合にあわせるしかない。筆者らの研究では，5週間 にわたり平日はもちろん土曜日の夜間, 日曜日にも参加 できるよら受診枠を設定し，参加者に都合の良い日時を 選択してもらった結果，2回実施した精液検査いずれか への参加率は $33 \%$ (54 人中 18 人，各回の参加率は $26 \%$ と 28\%) となり（7），別の職域で事業所内定期健康診断 にあわせ 2 回実施した際の参加率 $11 \%$ （70人中 8 人，各 回の参加率は $10 \%$ と 4\%）を上回った。前者の研究では 当初参加への関心を示した人が実際の参加者の 2 倍近く にのぼり，設定した健康診断会場が自動車で 1 時間近く かかる郊外の病院であったことを考慮すると，会場が職 場からもっと近ければ参加率はさらに高くなった可能性 があった。後者の研究との参加率の差が何によるのかは 厳密には議論できないが，精液健康診断の会場は事業所 の外に設定した方が心理的に参加しやすいのではと考え られる。

\section{5. 精液指標測定值に関連する要因}

正確な精液指標調査を行らためには，測定における系 統誤差や非系統誤差の原因となる因子について理解して おく必要がある。WHO は検査標準化のための留意点を 詳細に述べたマニュアルを刊行 (33) し，これが世界的に 広く用いられているが，ここではマニュアルが触れてい
ない点を含めて概説したい。精子濃度は同一人から精液 を複数回採取した場合に 10 倍以上の変動を示すことも 少なくないばらつきの大きい指標である (33)。精子濃度 は禁欲期間が長くなると増加する一方，精子運動率，正 常形態精子率は 1 週間程度までは大きな変化はなく，10 日を超えると低下する（34-38）。したがって，マニュア ルでは禁欲期間は 48 時間以上 7 日以内が望ましいとさ れ (33), 参加者に対してはあらかじめこのことを告げて おく必要があるが，この期間内でも濃度は経時的に変化 し(34-37), 比較する群間で禁欲期間が異なるとその違 いが指標の差となって現れる可能性がある。したがって, 禁欲日数幅をさらに短く統一できれば望ましいが，研究 者の指示通りにそれがきちんと行われるとは限らないの で，解析時に調整できるよう精液試料提出時に禁欲時間 を聴取する必要がある。

精液採取を複数の季節にわたり行ら場合，精液質の季 節变動も考慮の対象となる。最近は季節変動がそしいと する研究が報告されている $(35,39)$ が，夏季の精液質は 一年のらちで最も低下寸るとする報告が多く(40-42), 異なる季節に採取した精液の指標をプールして解析する には慎重であった方がよい。

また，マスターベーションにより得られる精液の各指 標については, 射精前の性的興奮時間の長さが有意に影 響することが報告されている (43)。職域集団を対象とす る調査では不妊外来の採精室のように採精条件を同一に できるとは限らないが，射精に至るまでの採精時の環境 はできれば調査を通して統一することが望ましい。採精 場所を被験者の自宅とする場合は，採精環境の他に精液 提出までの時間, 温度条件も精子運動率に影響を及ぼす ので，さらに注意が必要になる $(2,33)$ 。

ヒトの精液は射精直後には粘性が高く，時間が経過す ると粘性が低下（液化）する。液化に要する時間はサン プルによって異なるが，十分に液化しないと安定したピ ペッティング操作が困難になるなど，計測值が変動する 原因となる。また，精子濃度が著しく低い場合，あるい は著しく高い場合は，分析サンプルの希釈倍率を変えて 適切な濃度に調整することが重要であり, この点, WHO マニュアルが推奨する血球計算板とそれ以外の方法，す なわち, CASA（精子指標自動解析装置）や希釈しない で測定可能な Makler チャンバーを用いた精子濃度測定 結果とが，必ずしも一致するとはいえない理由のひとつ となっている (33)。また, 精子の運動性, 形態の評価に 関しては，精子濃度以上に測定者によるばらつき（測定 バイアス）が生じやすい(44)。したがって，異なる施設 間のデータを比較する場合, 精液指標の測定法標準化に 正面から取り組んだ研究 (45-47) のようによくコント ロールされている場合を除き，注意が必要である。将来 的には，測定者によるバイアスがより小さい新たな指標 を開発・導入し，既存の指標と併用することがめざされ るべきである。当面この問題を回避するには, 調査を通 して同じ測定者が全被験者のサンプルを曝露に関する情 
報なしで測定し，WHO マニュアルの基準値を用いた正 常，異常の分類を行わず，曝露・非曝露群間で測定值の 比較をするのがよい。

ライフスタイル要因のらちでは，契煙や飲酒が精液指 標低下に関係があるかについて議論があり，影響すると の報告もある $(48,49)$ ので, 群間の差が大きい場合には 調整した方がよいと考えられる。

この他に考慮する必要があるのは，交絡因子として年 齢 (50-52)，精索静脈瘤 (31)，放射線や抗ガン剂による 治療歴，長期の服薬歴等があげられる。分裂細胞への影 響が明らかな放射線や抗ガン剂が性腺細胞に作用するこ とはよく知られた事実であるが $(53,54)$ ， ライディッヒ 細胞のステロイド合成に影響を与える薬物も精子形成に 悪影響を与え (54), このような薬の内服で女性化乳房と ともに乏精子症の生じた報告 (55) がある。長期投与が行 われる薬剤の中で女性化乳房の副作用がある薬物は少な くないが，副作用報告に明記されていなくても性腺機能 に影響を及ぼす可能性に留意し，このような薬物を長期 間服用している被験者は研究としての解析から除いた方 がよいと考えられる。

\section{6. 結果の解釈と被験者への結果返却の問題}

研究的な性格が強くとも健康診断として調査を行った 場合，その結果は被験者に返さなければならないが，精 液指標をはじめとする生殖機能測定結果の解釈には慎重 な姿勢と配慮が求められる。精液指標は同一個人でも測 定ごとの変動幅が大きく, また, 前章で触れたように年 齢の影響を受ける。そして, WHO の参照值を職域健康 診断の結果判定に用いる際には，特に乏精子症に該当す る場合の判定の表現には注意を払うべきで, 不用意に「乏 精子症の人は子供ができにくい」と伝えることは慎まな くてはならない。筆者は常に, 検査結果はその時により 大きく変動すること, 一度の精液検査結果で妊孕性に関 して判断することはできないことをよく説明すると同時 に, 生殖機能の健康に不安がある場合は専門医が相談に 応じることのできる体制を用意している。

しかし, 調査研究への参加者に無精子症などの深刻な 機能低下所見が最終的に確認された場合，医療面でのケ アとは別に労災問題が思いもかけない形で発生する可能 性があるので注意が必要である。業務起因性の有無の判 断にあたっては，他の業務上疾病（職業病）の場合と同 様に，曝露している物質の種類，曝露量，曝露期間，鑑 別診断, 検査結果の推移及び曝露との時間的関係, 生殖 歴を含む既往歴，職業歴，同様に懪露している他の人の 検査結果等を含め総合的に判断することになる。しかし， 曝露前後の情報のない 1 時点での検査結果をもって曝露 と精液指標低下との因果関係を証明することは困難で, 不妊などの生殖機能低下との因果関係の言及にはさらに 慎重であるべきである。

\section{7. まとめ}

以上をまとめると，職域における精液指標に関する調 査研究では，健康診断結果にもとづく事業所としての対 応の問題, 参加者のプライバシ一の確保, 心理的抵抗を 低くし参加率を高めるための工夫の余地の大きさ，偶然 測定誤差を小さくする観点からみて，現状では事業所外 に健康診断会場を設定し，対象者には事業所とは無関係 な形で参加してもらら方法が比較的スムーズに実施可能 であると考えられる。1 回の横断研究, 特に対象者数の 少ない調査から得た結果の結論づけには慎重な姿勢が必 要であるが，その結果は，将来七トと実験動物との種差 が定量的に解明され，毒性機序に基づくリスク評価手法 が発展した後でも，最も基本的な情報になると考えられ る。職域集団を対象とした生殖機能のリスク評価が我が 国でももっと積極的に行われるようになることを期待 し，結びの言葉としたい。

\section{謝辞}

本総説の執筆にあたっては, 平成 14-16 年度厚生労働 科学研究費補助金 (化学物質リスク研究事業), 日本学術 振興会の科学研究費補助金の助成を得た。

\section{文献}

(1) Carlsen E, Giwercman A, Keiding N, Skakkebaek NE. Evidence for decreasing quality of semen during past 50 years. BMJ. 1992;305:609-613.

(2) Schrader SM. General techniques for assessing male reproductive potential in human field studies. In: Chapin RE, Heindel JJ eds. Male Reproductive Toxicology. San Diego: Academic Press, 1993:362-371.

( 3 ) Whorton D, Krauss RM, Marshall S, Milby TH. Infertility in male pesticide workers. Lancet. 1977;2:1259-1261.

(4) Kim Y, Jung K, Hwang T, Jung G, Kim H, Park J, Kim J, Park J, Park D, Park S, Choi K, Moon Y. Hematopoietic and reproductive hazards of Korean electronic workers exposed to solvents containing 2-bromopropane. Scand J Work Environ Health. 1996;22:387-391.

(5) Xia Y, Cheng S, Bian Q, Xu L, Collins MD, Chang HC, Song L, Liu J, Wang S, Wang X. Genotoxic effects on spermatozoa of carbaryl-exposed workers. Toxicol Sci. $2005 ; 85: 615-623$.

(6) Dalvie MA, Myers JE, Thompson ML, Robins TG, Dyer S, Riebow J, Molekwa J, Jeebhay M, Millar R, Kruger P. The long-term effects of DDT exposure on semen, fertility, and sexual function of malaria vector-control workers in Limpopo Province, South Africa. Environmental Research. 2004;96:1-8.

( 7 ) Kamijima M, Hibi H, Gotoh M, Taki K, Saito I, Wang H, Itohara S, Yamada T, Ichihara G, Shibata E, Nakajima T, Takeuchi Y. A survey of semen indices in insecticide sprayers. J Occup Health. $2004 ; 46$ : 109-118. 
( 8 ) Xia Y, Bian Q, Xu L, Cheng S, Song L, Liu J, Wu W, Wang S, Wang X. Genotoxic effects on human spermatozoa among pesticide factory workers exposed to fenvalerate. Toxicology. 2004;203: 49-60.

( 9 ) Sanchez-Pena LC, Reyes BE, Lopez-Carrillo L, Recio R, Moran-Martinez J, Cebrian ME, Quintanilla-Vega B. Organophosphorous pesticide exposure alters sperm chromatin structure in Mexican agricultural workers. Toxicol Appl Pharmacol. 2004;196:108-113.

(10) Rignell-Hydbom A, Rylander L, Giwercman A, Jonsson BA, Nilsson-Ehle P, Hagmar L. Exposure to CB-153 and p,p'-DDE and male reproductive function. Hum Reprod. $2004 ; 19: 2066-2075$.

(11) Kumar S, Zaidi S, AK G, Dave L, Saiyed H. Semen quality and reproductive hormones among welders - a preliminary study. Environ Health Prev Med. 2003; 8:64-67.

(12) Forkert P-G, Lash L, Tardif R, Tanphaichitr N, Vandevoort C, Moussa M. Identification of trichloroethylene and its metabolites in human seminal fluid of workers exposed to trichloroethylene. Drug Metabolism and Disposition. 2003; $31: 306-311$.

(13) Bonde JP, Joffe M, Apostoli P, Dale A, Kiss P, Spano M, Caruso F, Giwercman A, Bisanti L, Porru S, Vanhoorne M, Comhaire F, Zschiesche W. Sperm count and chromatin structure in men exposed to inorganic lead: lowest adverse effect levels. Occup Environ Med. 2002; 59:234-242.

(14) Recio R, Robbins WA, Ocampo-Gomez G, Borja-Aburto V, Moran-Martinez J, Froines JR, Hernandez RMG, Cebrian ME. Organophosphorous pesticide exposure increases the frequency of sperm sex null aneuploidy. Environ Health Perspect. $2001 ; 109: 1237-1240$.

(15) Wang SL, Wang XR, Chia SE, Shen HM, Song L, Xing HX, Chen HY, Ong CN. A study on occupational exposure to petrochemicals and smoking on seminal quality. J Androl. $2001 ; 22: 73-78$.

(16) Celis RD, Feria-Velasco A, Gonzalez-Unzaga M, TorresCalleja J, Pedron-Nuevo N. Semen quality of workers occupationally exposed to hydrocarbons. Fertil Steril. $2000 ; 73: 221-228$.

(17) Abell A, Ernst E, Bonde JP. Semen quality and sexual hormones in greenhouse workers. Scand J Work Environ Health. $2000 ; 26: 492-500$.

(18) Harkonen K, Viitanen T, Larsen SB, Bonde JP, ASCLEPIOS, Lahdetie J. Aneuploidy in sperm and exposure to fungicides and lifestyle factors. Environ Mol Mutagen. 1999;34:39-46.

(19) Larsen SB, Giwercman A, Spano M, Bonde JP. Seminal characteristics following exposure to pesticides among agricultural workers. Scand J Work Environ Health. 1999; 25(suppl 1):74-75.

(20) Juhler R, Larsen SB, Meyer O, Jensen N, Spano M, Giwercman A, Bonde JP. Human semen quality in relation to dietary pesticide exposure and organic diet. Arch Environ Contam Toxicol. 1999;37:415-423.

(21) Kolstad HA, Bonde JP, Spano M, Giwercman A, Zschiesche W, Kaae D, Larsen SB, Roeleveld N,
ASCLEPIOS. Change in semen quality and sperm chromatin structure following occupational styrene exposure. Int Arch Occup Environ Health. 1999;72:135141.

(22) Tomenson JA, Taves DR, Cockett AT, McCusker J, Barraj L, Francis M, Pastoor TP, Wickramaratne GA, Northrop HL. An assessment of fertility in male workers exposed to molinate. J Occup Environ Med. 1999;41:771-787.

(23) Arbuckle TE, Schrader SM, Cole D, Hall JC, Bancej CM, Turner LA, Claman P. 2,4-Dichlorophenoxyacetic acid residues in semen of Ontario farmers. Reprod Toxicol. 1999; 13:421-429.

(24) Padungtod C, Hassold T, Millie E, Ryan LM, Savitz D, Christiani DC, Xu X. Sperm aneuploidy among Chinese pesticide factory workers: scoring by the FISH method. Am J Ind Med. 1999;36:230-238.

(25) Padungtod C, Savitz DA, Overstreet JW, Christiani DC, Ryan $\mathrm{LM}, \mathrm{Xu} \mathrm{X}$. Occupational pesticide exposure and semen quality among Chinese workers. J Occup Environ Med. 2000;42:982-992.

(26) Ichihara G, Ding X, Yu X, Wu X, Kamijima M, Peng S, Jiang $\mathrm{X}$, Takeuchi $\mathrm{Y}$. Occupational health survey on workers exposed to 2-bromopropane at low concentrations. Am J Ind Med. 1999; 35:523-531.

(27) Slutsky M, Levin JL, Levy BS. Azoospermia and oligospermia among a large cohort of DBCP applicators in 12 countries. Int J Occup Environ Health. 1999; 5:116-122.

(28) Welch LS, Schrader SM, Turner TW, Cullen MR. Effects of exposure to ethylene glycol ethers on shipyard painters: II. Male reproduction. Am J Ind Med. 1988; 14:509-526.

(29) Apostoli P, Kiss P, Porru S, Bonde JP, Vanhoorne M. Male reproductive toxicity of lead in animals and humans. ASCLEPIOS Study Group. Occup Environ Med. 1998;55:364-374.

(30) Evers JL. Female subfertility. Lancet. 2002;360:151-159.

(31) Cozzolino DJ, Lipshultz LI. Varicocele as a progressive lesion: positive effect of varicocele repair. Hum Reprod Update. $2001 ; 7: 55-58$.

(32) Slama R, Eustache F, Ducot B, Jensen T, Jorgensen N, Horte A, Irvine S, Suominen J, Andersen A, Auger J, Vierula M, Toppari J, Andersen A, Keiding N, Skakkabaek $\mathrm{N}$, Spira A, Jouannet P. Time to pregnancy and semen parameters: a cross-sectional study among fertile couples from four Europian cities. Hum Reprod. 2002;17:503515.

(33) World Health Organization. WHO Laboratory Manual for the Examination of Human Semen and Sperm-cervical Mucus Interaction. 4th ed. Cambridge: Cambridge University Press, 1999.

(34) De Jonge C, LaFromboise M, Bosmans E, Ombelet W, Cox A, Nijs M. Influence of the abstinence period on human sperm quality. Fertil Steril. 2004;82:57-65.

(35) Carlsen E, Petersen JH, Andersson AM, Skakkebaek NE. Effects of ejaculatory frequency and season on variations in semen quality. Fertil Steril. 2004;82:358-366.

(36) Magnus O, Tollefsrud A, Abyholm T, Purvis K. Effects of 
varying the abstinence period in the same individuals on sperm quality. Arch Androl. $1991 ; 26: 199-203$.

(37) Blackwell JM, Zaneveld LJ. Effect of abstinence on sperm acrosin, hypoosmotic swelling, and other semen variables. Fertil Steril. 1992;58:798-802.

(38) Pellestor F, Girardet A, Andreo B. Effects of long abstinence periods on human sperm quality. Int J Fertil Menopausal Stud. 1994;39:278-282.

(39) Malm G, Haugen TB, Henrichsen T, Bjorsvik C, Grotmol T, Saether T, Malm J, Figenschau Y, Hagmar L, Rylander L, Levine RJ, Giwercman A. Reproductive function during summer and winter in Norwegian men living north and south of the Arctic circle. J Clin Endocrinol Metab. 2004; 89:4397-4402.

(40) Levine RJ. Seasonal variation of semen quality and fertility. Scand J Work Environ Health. 1999;25(suppl1):34-37.

(41) Centola GM, Eberly S. Seasonal variations and age-related changes in human sperm count, motility, motion parameters, morphology, and white blood cell concentration. Fertil Steril. 1999;72:803-808.

(42) Gyllenborg J, Skakkebaek NE, Nielsen NC, Keiding N, Giwercman A. Secular and seasonal changes in semen quality among young Danish men: a statistical analysis of semen samples from 1927 donor candidates during 19771995. Int J Androl. 1999;22:28-36.

(43) Pound N, Javed MH, Ruberto C, Shaikh MA, Del Valle AP. Duration of sexual arousal predicts semen parameters for masturbatory ejaculates. Physiol Behav. 2002;76:685-689.

(44) Jorgensen N, Auger J, Giwercman A, Irvine DS, Jensen TK, Jouannet P, Keiding N, Le Bon C, MacDonald E, Pekuri AM, Scheike T, Simonsen M, Suominen J, Skakkeboek NE. Semen analysis performed by different laboratory teams: an intervariation study. Int J Androl. 1997;20:201-208.

(45) Jorgensen N, Andersen AG, Eustache F, Irvine DS, Suominen J, Petersen JH, Andersen AN, Auger J, Cawood EH, Horte A, Jensen TK, Jouannet P, Keiding N, Vierula M, Toppari J, Skakkebaek NE. Regional differences in semen quality in Europe. Hum Reprod. $2001 ; 16: 1012-1019$.
(46) Giwercman A, Spano M, Lahdetie J, Bonde JP. Quality assurance of semen analysis in multicenter studies. Asclepios. Scand J Work Environ Health. 1999;25 Suppl $1: 23-25$.

(47) Jorgensen N, Carlsen E, Nermoen I, Punab M, Suominen J, Andersen AG, Andersson AM, Haugen TB, Horte A, Jensen TK, Magnus O, Petersen JH, Vierula M, Toppari $J$, Skakkebaek NE. East-West gradient in semen quality in the Nordic-Baltic area: a study of men from the general population in Denmark, Norway, Estonia and Finland. Hum Reprod. 2002;17:2199-2208.

(48) Rubes J, Lowe X, Moore D, 2nd, Perreault S, Slott V, Evenson D, Selevan SG, Wyrobek AJ. Smoking cigarettes is associated with increased sperm disomy in teenage men. Fertil Steril. 1998;70:715-723.

(49) Martini AC, Molina RI, Estofan D, Senestrari D, Fiol de Cuneo M, Ruiz RD. Effects of alcohol and cigarette consumption on human seminal quality. Fertil Steril. 2004; $82: 374-377$.

(50) Kidd S, Eskenazi B, Wyrobek A. Effects of male age on semen quality and fertility: a review of the literature. Fertil Steril. $2001 ; 75: 237-248$.

(51) Jung A, Schuppe HC, Schill WB. Comparison of semen quality in older and younger men attending an andrology clinic. Andrologia. 2002;34:116-122.

(52) Eskenazi B, Wyrobek AJ, Sloter E, Kidd SA, Moore L, Young S, Moore D. The association of age and semen quality in healthy men. Hum Reprod. 2003; 18:447-454.

(53) Cleary SF. Reproductive toxic effects of electromagnetic radiation. In: Witorsch RJ ed. Reproductive Toxicology. New York: Raven Press, 1995:265-282.

(54) Sundaram K, Witorsch RJ. Toxic effects on the testes. In: Witorsch RJ ed. Reproductive Toxicology. New York: Raven Press, 1995:99-121.

(55) Pont A, Graybill JR, Craven PC, Galgiani JN, Dismukes WE, Reitz RE, Stevens DA. High-dose ketoconazole therapy and adrenal and testicular function in humans. Arch Intern Med. $1984 ; 144: 2150-2153$. 